\title{
Predatory Behavior and Web Structure of Meta menardi (Araneae: Tetragnathidae)
}

\author{
Makoto YoshidA $^{1)}$ and Akira SHINKAI ${ }^{2)}$
}

吉田 真 $^{1)} \cdot$ 新海 明 ${ }^{2)}$ ：サンロウドヨウグモの捕食行動と網構造

\begin{abstract}
The predatory behavior and the web structure of Meta menardi were studied, and the natural prey was collected from its webs. This species employed four predatory sequences, Bite-Pull out, Bile-Wrap, Wrap-Bite and Wrap. WrapBite and Wrap were employed to ants and a millipede. Diptera were attacked only by biting. "Wrap" may be the predatory sequence in order to capture millipedes secreting venomous substances such as hydrocyanic acid.
\end{abstract}

Three Japanese species of Metleucauge (M. kompirensis, M. yunohamensis, and M. yaginumai) capture mainly midges and mayflies above stream. In the capture of prey insects restrained by the web, these spiders always attack them by biting (attack biting), and not by wrapping with silk (lack of attack wrapping) (YosHIDA, 1989).

On the other hand, spiders of Meta reticuloides attack its prey both by biting and by wrapping (YoshidA, 1990). However, it was not known whether the other species of Meta use attack wrapping or not.

So, we investigated the predatory behavior and web structure of another Japanese species of the genus Meta, Meta menardi (LATREILLE, 1804), and found that this species alto use attack wrapping. Furthermore, in some cases, it carried its prey without biting after attack wrapping.

In this paper, we report these results and discuss the reasons for the differences on the predatory behavior between Meta and Metleucauge.

\section{Materials and Methods}

The investigation was done in 1990 and 1991 in and near Komori-ana, a cave at the foot of Mt. Fuji, Japan. In the study of predatory behavior, we observed the predatory sequences employed both on natural prey hit the web and on the prey given by us.

We measured the web size, estimated the body length of spiders by eye, and counted the number of spirals, radii and frame threads of webs.

1) Department of Biology, Faculty of Science and Engineering, Ritsumeikan University, Kitaku, Kyoto, 603-77 Japan

立命館大学理工学部生物学教室

2) Department of Zoology, Faculty of Science, Kyoto University, Sakyo-ku, Kyoto, 606 Japan 京都大学理学部動物学教室

Accepted May 6, 1993 


\section{Results}

\section{Attack sequences employed}

Four attack sequences were observed as follows:

Bite-Pull out (BP): Spiders bit the prey for several seconds, pulled it from the web with the jaws, carried to the feeding sites. There were two carrying methods as follows: 1) Carrying the prey along a radial thread, or 2) "drop and climb up" behavior (dropping from the web, hanging with the dragline attached to the hub and climbing to the hub along the dragline).

Bite-Wrap (BW): Spiders bit the prey for several seconds or more, wrapped it with silk, cut the silk entangling the prey, and carried it suspended on a silk line.

Wrap-Bite (WB): Spiders wrapped the prey with silk, bit it for a few seconds, cut the entangling silk, and carried it suspended on a silk line.

Wrap (W): Spiders wrapped the prey with silk, but did not bite it at the capture site. Then they cut the entangling silk, and carried it suspended on a silk line.

\section{Frequency of attack sequences with different types and sizes of prey}

Table 1 shows the frequency of sequences with different types of prey. Dipterans were always attacked by biting (BP or BW), while ants were always attacked by wrapping (WB or W). Spiders could not capture $33 \%$ of ants supplied (3/9). A millipede was attacked by wrapping also (W). In $83 \%(5 / 6)$ of the cases of capturing ants, the spiders touched the prey with legs I before they attacked.

Table 2 shows that $M$. menardi captured larger Diptera with Bite-Wrap, smaller Diptera with Bite-Pull out, though the ranges overlapped. In the capture of ants,

Table 1. Frequency of attack sequences with different types of prey in Meta menardi.

\begin{tabular}{lccccccc}
\hline \multirow{2}{*}{ Prey type } & \multicolumn{4}{c}{ Attack sequences employed } & $\begin{array}{c}\text { Total } \\
\text { prey } \\
\text { captured }\end{array}$ & $\begin{array}{c}\text { Total } \\
\text { prey not } \\
\text { captured }\end{array}$ \\
\cline { 2 - 6 } & Bite-Pull out & Bite-Wrap & Wrap-Bite & Wrap & 1 & 1 & 0 \\
\hline $\begin{array}{c}\text { Diplopoda } \\
\text { (Millipede) }\end{array}$ & 0 & 0 & 0 & 1 & 11 & 0 \\
$\begin{array}{l}\text { Diptera } \\
\text { Hymenoptera }\end{array}$ & 2 & 9 & 0 & 0 & & \\
Ants & 0 & 0 & 2 & 4 & 6 & 3 \\
$\quad$ Wasps & 0 & 0 & 0 & 0 & 0 & 1 \\
Total & 2 & 9 & 2 & 5 & 18 & 4 \\
\hline
\end{tabular}

Table 2. Frequency of attack sequences to relative prey size, in the capture of Diptera.

\begin{tabular}{lcccccc}
\hline & \multicolumn{7}{c}{ Relative body length (prey/spider) } \\
\cline { 2 - 7 } & $0-0.33$ & $0.34-0.67$ & $0.68-1.00$ & $1.01-1.33$ & 1.34 & Total \\
\hline Bite-Pull out & 1 & 1 & 0 & 0 & 0 & 2 \\
Bite-Wrap & 1 & 4 & 2 & 0 & 2 & 9 \\
\hline
\end{tabular}




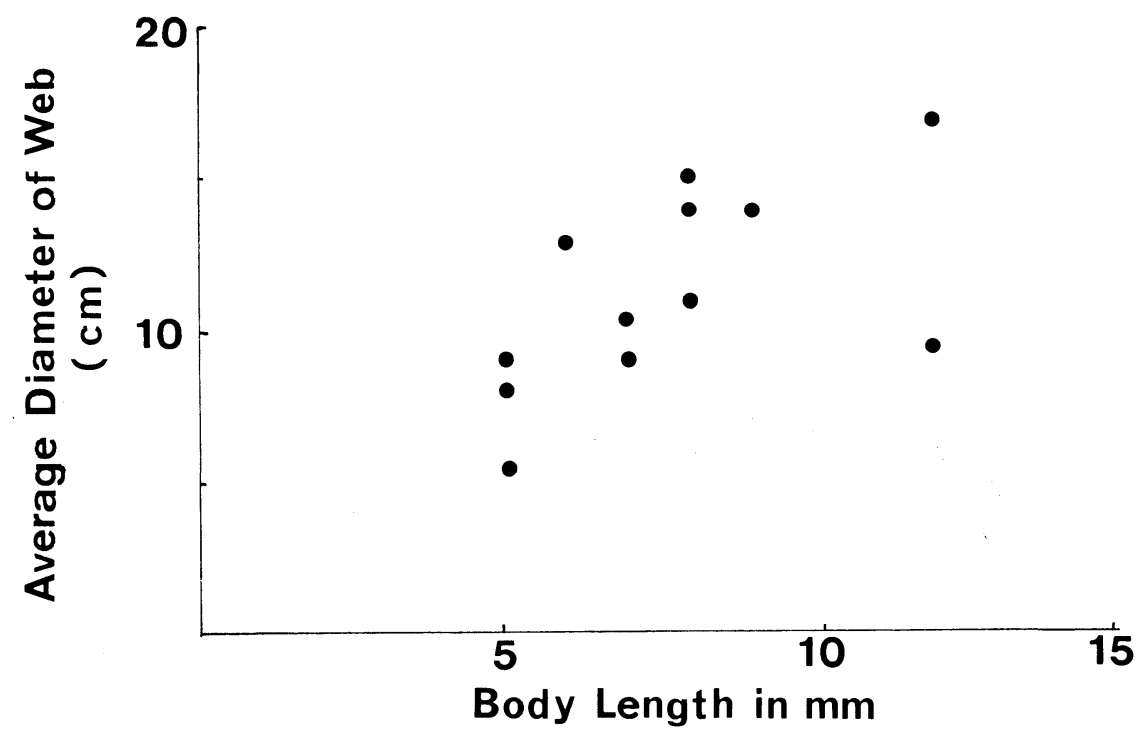

Fig. 1. Relation between the body length of $M$. menardi and the average diameter of its webs.

the relative body length of ants captured with Wrap-Bite is $0.49 \pm 0.09$ (Mean $\pm \mathrm{SD}$, $\mathrm{N}=2$ ), while that with Wrap is $1.02 \pm 0.31(\mathrm{~N}=4)$. So, Wrap seems to be the sequence with larger ants.

\section{Prey fauna}

The prey collected from webs were 5 millipedes (body length in $\mathrm{mm}: 2.5,3,6$, 6,8 ) and two dipterans (a midge, $1.5 \mathrm{~mm}$; a crane fly, $6 \mathrm{~mm}$ ).

\section{Web structure}

Webs of Meta menardi were found near the entrance in the cave, and among rocks outside the cave. In most cases, the webs were horizontal orbs with open hub similar to the webs of Metleucauge and Meta reticuloides, but some webs of $M$. menardi had free sector zones in which spirals were not span.

The webs become larger with body length $(r=0.56)$ (Fig. 1). The web diameter of adults was about $15 \mathrm{~cm}$. The number of spirals, radii and frame threads were $14.6 \pm 5.3($ Mean $\pm \mathrm{SD}, \mathrm{N}=42), 17.0 \pm 4.3(\mathrm{~N}=42)$ and $1.1 \pm 0.6(\mathrm{~N}=12)$, respectively. Radii were usually attached directly to the scaffolds, rocks, and rarely to the frame threads.

\section{Discussion}

Meta reticuloides uses attack wrapping with particular types of prey such as ants (YoshidA, 1990), and M. menardi shows similar behavior as shown in this study. So, attack wrapping may be characteristic of this genus. $M$. menardi used attack wrapping for ants and a millipede. It is well known that ants secrete formic acid and millipedes secrete hydrocyanic acid and other dangerous substances, when they are attacked. 
Meta reticuloides uses attack wrapping also for ants, bees, wasps, stink bugs and a large crane fly (YosHIDA, 1990). These insects also secrete venomous substances except cranefly. So, the main function of attack wrapping in these spiders may be to avoid these dangerous substances.

However, ants seem to be unusual prey of $M$. menardi, because ants were not collected from their webs and because the webs were found in dark places such as in caves or among rocks and ants were not found there. Furthermore, pery-touching was done only in the capture of ants. This is probably a behavior for obtaining more information on unusual prey restrained by the web.

On the other hand, millipedes may be a main prey of $M$. menardi, because they were collected from the webs, and because they are very abundant in caves. "Wrap", i.e. attack wrapping and carrying without biting at the capture site, is a unique attack sequence found only in the predatory behavior of $M$. menardi, and never found in that of Metleucauge species and Meta reticuloides. $M$. menardi captured a millipede by "Wrap", so, the sequence may have developed to capture millipedes, because they secrete very dangerous substances such as hydrocyanic acid, and because even biting soon after attack wrapping may be dangerous for the spider.

LEVI (1980) stated that Meta species are found in dark places, and are common in caves. Though $M$. reticuloides is not found in caves, M. menardi, M. dolloff, $M$. bourneti are found in caves (LEVI, 1980; SHINKAI and TAKANO, 1984; RoBERTS, 1985; YAginuma, 1986; ChiKuni, 1989; YoshidA, 1990).

The third Japanese species of Meta, not described yet, is also found in caves (YAGINUMA and BANDO, personal communication).

Meta must have adapted to inhabit in caves. For example, $M$. menardi usually attaches its radii directly to rocks, not to the frame thread, as shown in the results. This is probably because the spider makes its web at concavities of the wall or among rocks in caves and frame threads were not necessary to make the web.

Attack wrapping of Meta spiders may be another example of an adaptation to live in caves; that is, it may have developed originally to capture millipedes in caves. In the case of $M$. reticuloides which does not inhabit in caves (SHINKAI and TAKANO, 1984; Yaginuma, 1986; ChIKUNI, 1989; YoshidA, 1990), the ability of attack wrapping is not necessary, because almost all the prey are dipteran insects flying weakly such as midges, though the spider can use attack wrapping to dangerous and/or large prey if they are given (YosHIDA, 1990).

Besides, one North American and three Japanese species of Metleucauge make their webs above streams (LeVI, 1980; Yoshida, 1989). M. chikunii, the fourth Japanese species of the genus recently described by TANIKAWA (1992), also does so (YoshIDA, unpublished data). Their main prey is small dipterants and mayflies (YoshidA, 1989).

It is not neccesary to use attack wrapping for their small and/or weak prey. They make their webs in the evening when many midges and mayflies fly above streams, and capture them in the evening and at night (Yoshida, 1977, 1989), while the webs of $M$. reticuloides and $M$. menardi can be found all the day. Metleucauge does not use attack wrapping even to dangerous prey given to the web (YoSHIDA, 1989), while Meta does (YosHidA, 1990 and this study).

If the common ancester of Meta and Metleucauge used attack wrapping, Metleucauge may have lost the ability of attack wrapping because of its non-dangerous 
prey. On the contrary, if the common ancester did not use attack wrapping, Meta may have developed the ability in order to capture millipedes.

\section{Acknowledgements}

We would like to express our thanks to Mr. E. SHINKAI for teaching us the habitat of M. menardi, and to Mr. T. YoshidA and H. Iто of Nature Cine Production for lodging and helping our investigation.

\section{摘 要}

富士山麓の溶岩洞の一つである蝙蝠穴とその付近で，サンロウドヨウグモの捕食行動之 網構造の調查を行った。このクモはヤマジドヨウグモと同様に，網にかかった特定のタイ プの慨に対して糸の投げかけによって攻撃した（攻撃ラッピング）。オオドヨウグモ属の 各種は攻撃ラッピングを行わず，ドヨウグモ属の 2 種はそれを行うことから, 攻撃ラッピ ングはドヨウグモ属の行動上の一特性かもしれない.

\section{References}

ChikUni, Y., 1989. Pictorial Encyclopedia of Spiders in Japan. 308 pp. Kaiseisha, Tokyo. (In Japanese.)

LEVI, H. W., 1980. The orb-weaver genus Mecynogea, the subfamily Metinae and the genera Pachygnatha, Glenognatha and Azilia of the subfamily Tetragnathinae north of Mexico (Araneae: Araneidae). Bull. Mus. comp. Zool., 149: 1-74.

RoberTS, M. J., 1985. The spiders of Great Britain and Ireland, Vol. 1. Atypidae to Theridiosomatidae. 229 pp. Harley Books, Colchester.

Shinkai, E., \& S. TaKano, 1984. A Field Guide to the Spider of Japan. 204 pp. Tokai Univ. Press, Tokyo. (In Japanese.)

Tanikawa, A., 1992. A revision of the Japanese spiders of the genus Metleucauge Levi, 1980 (Araneae: Tetragnathidae). Acta arachnol., 41: 161-176.

YAGinuma, T., 1986. Spiders of Japan in Color. 305 pp. Hoikusha, Osaka. (In Japanese.)

YoshIDA, M., 1977. Web site selection of four spider species inhabiting streamsite-An analysis on the factors of coexistence in relation to prey abundance. Acta arachnol., 27 (special number): 261-282. (In Japanese, with English synopsis.)

1989. Predatory behavior of three Japanese species of Melteucauge (Araneae: Tetragnathidae). J. Arachnol., 17: 15-25.

1990. Predatory behavior of Meta reticuloides YAGINUma (Araneae: Tetragnathidae). Acta arachnol., 39: 27-38. 